Janssen, Lilly, Merck, Novartis, Pfizer, Regeneron, Samsung, Sanofi and UCB, K. McQuarrie Shareholder of: Janssen Research \& Development, LLC, Employee of: Janssen Research \& Development, LLC, N. Li Shareholder of: Janssen Research \& Development, LLC, Employee of: Janssen Research \& Development, LLC, R. Ganguly Shareholder of: GlaxoSmithKline, Employee of: GlaxoSmithKline DOI: 10.1136/annrheumdis-2017-eular.3917

\section{FRI0247 MEDIAN TIME TO LOW DISEASE ACTIVITY IS SHORTER IN TOCILIZUMAB COMBINATION THERAPY WITH CSDMARDS AS COMPARED TO MONOTHERAPY IN PATIENTS WITH ACTIVE RHEUMATOID ARTHRITIS AND INADEQUATE RESPONSES TO CSDMARDS AND/OR TNF INHIBITORS: SUBANALYSIS OF THE SWISS AND AUSTRIAN PATIENTS FROM THE ACT-SURE STUDY}

R. Mueller ${ }^{1}$, W. Graninger ${ }^{2}$, P. Sidiropoulos ${ }^{3}$, C. Goger ${ }^{4}$, J. von Kempis ${ }^{1}$. ${ }^{1}$ Division of Rheumatology, Kantonsspital St. Gallen, St. Gallen, Switzerland; ${ }^{2}$ Division of Rheumatology, Medical University of Graz, Graz, Australia; ${ }^{3} \mathrm{~F}$. Hoffmann-La Roche Ltd., South San Francisco, United States; ${ }^{4}$ Roche Austria $\mathrm{GmbH}$, Vienna, Austria

Background: To analyze efficacy and safety of tocilizumab in patients with rheumatoid arthritis (RA) and an inadequate response to conventional synthetic disease modifying anti-rheumatic drugs (csDMARDs) and/or tumour necrosis factor (TNF) inhibitors of the Swiss and Austrian patients from the ACT-SURE study.

\section{Objectives:}

Methods: Sub-analysis of RA patients from Switzerland and Austria, who participated in the international phase Illb, open-label, ACT-SURE study. Patients with an inadequate response to csDMARDs or TNF antagonists were included into the study receiving $8 \mathrm{mg} / \mathrm{kg}$ of IV tocilizumab every 4 weeks during a 24 week time period. Therapy with one or more csDMARDs could be continued as combination therapy with tocilizumab (Combo) or stopped, resulting in tocilizumab monotherapy (Mono), at the treating physician's discretion. These two patient groups were analyzed in separate and compared.

Results: Overall, 107 (22 on Mono vs 85 on Combo and) patients were treated with tocilizumab. The percentage of patients with at least one adverse event was significantly lower in the tocilizumab combination (58.8\%) as compared to the monotherapy group (81.8\%, $\mathrm{p}=0.0458)$. No differences in ACR20/50/70/90 response rates were observed between both treatment groups at week 24 (Mono: $63.6 \%, 40.9 \%, 22.7 \%$, and $18.2 \%$ vs. Combo: $61.2 \%, 43.5 \%, 25.9 \%$, and $10.6 \%$ ). The median time to low disease activity (LDA) was significantly shorter in patients treated with tocilizumab combination therapy Mono: 9.1, Combo 7.9 weeks, Log Rank $\mathrm{p}=0.038$ )

Conclusions: In this post hoc regional sub-analysis of the ACT-SURE study no differences for disease activity were found comparing the two patient groups at week 24. However, median time to LDA was statistically shorter in patients treated with tocilizumab combination therapy as compared to tocilizumab monotherapy. Consequently, adding tocilizumab to csDMARD therapy rather than changing to tocilizumab monotherapy may be, in our opinion, the safest strategy to reach maximum effect in RA patients with active disease despite treatment with CSDMARD. csDMARDs can be withdrawn either immediately due to adverse events or after at least low disease activity has been reached.

Disclosure of Interest: None declared

DOI: 10.1136/annrheumdis-2017-eular.5903

\section{FRI0248 INCIDENCE OF MELANOMA IN PATIENTS WITH RHEUMATOID ARTHRITIS TREATED WITH TOCILIZUMAB}

S. Gale ${ }^{1}$, J. Wang ${ }^{2}$, J.M. Nebesky ${ }^{3}$, A.T. Linke ${ }^{1}$, E. Berber ${ }^{1} .{ }^{1}$ Genentech, South San Francisco, CA, United States; ${ }^{2}$ Roche Products, Welwyn Garden City, United Kingdom; ${ }^{3}$ F. Hoffmann-La Roche, Basel, Switzerland

Background: There have been conflicting reports whether patients with rheumatoid arthritis (RA) receiving conventional or biologic immunosuppressive therapies are at increased risk of specific malignancies. Melanoma is an aggressive malignancy with risk factors including sex, age, fair skin and elevated cumulative UV exposure. Interleukin-6 (IL-6) has a role in pro- and antitumorigenic pathways. Whether tocilizumab (TCZ), a biologic that alters IL-6 signaling, increases the risk of melanoma in patients with RA is unclear.

Objectives: This age- and sex-adjusted standardized incidence ratio (SIR) analysis compared the observed reports of melanoma in patients with RA treated with TCZ in clinical trial and postmarketing settings with the expected number of cases across geographic regions.

Methods: SIRs for melanoma were calculated from the TCZ clinical trials allexposure population. Postmarketing rates were estimated from the TCZ Global Safety Database population. Both databases were searched cumulatively from 11 April 2005 to 10 October 2015. For clinical trials, observed reports of melanoma in patients with RA treated with TCZ were compared with expected number of cases in the general population based on the 2012 US Surveillance, Epidemiology, and End Results using an age- and sex-adjusted SIR. Postmarketing regional SIRs were calculated based on the estimated commercial exposure in each region and the incidence of melanoma as reported by Globocan by age and sex (2012).
Crude postmarketing rates were age- and sex-adjusted according to the clinical trial demographic profile to estimate the expected number of cases of melanoma in each region.

Results: In the clinical trial setting, 4 qualifying cases of melanoma were identified among 7093 patients with RA treated with TCZ (20,828 PY of exposure). The SIR estimate $(0.71$ [95\% Cl, 0.19-1.81]) for melanoma incidence in patients with RA treated with TCZ in clinical trials was comparable to that in the general population (Table 1). In the postmarketing setting, the number of observed reports of melanoma was comparable to the expected number of cases in Europe and Japan and fewer than expected in North America (Table 2). The exception is Australia, where SIR estimates indicated more than the expected number of cases in patients with RA receiving TCZ in Australia compared with the general population in that region (SIR 3.71 [95\% Cl: $2.16,5.93]$ )

Table 1. Incidence of melanoma in patients with RA from TCZ clinical trials, stratified by sex

\begin{tabular}{lcccc}
\hline Sex & $\begin{array}{c}\text { Observed } \\
\text { cases }^{\mathbf{a}}\end{array}$ & $\begin{array}{c}\text { Exposure } \\
\text { (PY) }\end{array}$ & $\begin{array}{c}\text { Expected } \\
\text { cases }^{\mathbf{b}}\end{array}$ & SIR $(95 \%$ CI) \\
\hline Female & 3 & 17,047 & 4.01 & $0.75(0.15,2.19)$ \\
\hline Male & 1 & 3781 & 1.66 & $0.60(0.02,3.35)$ \\
\hline All & 4 & 20,828 & 5.65 & $0.71(0.19,1.81)$ \\
\hline
\end{tabular}

a The age range of patients in the study cases was 50-64.

b Expected cases are based on Surveillance, Epidemiology, and End Results 2012 age-standardized incidence rates.

Table 2. Incidence of melanoma in patients with RA from TCZ postmarketing reports, stratified by region

\begin{tabular}{|c|c|c|c|c|}
\hline Region & $\begin{array}{c}\text { Observed } \\
\text { cases }\end{array}$ & $\begin{array}{l}\text { Region-Specific } \\
\text { Exposure (PY) }\end{array}$ & $\begin{array}{c}\text { Expected } \\
\text { cases }^{\circ}\end{array}$ & SIR (95\% CI) \\
\hline Europe & 30 & 126,683 & 26.6 & $1.13(0.76,1.61)$ \\
\hline North America & 17 & 131,546 & 36.9 & $0.46(0.27,0.74)$ \\
\hline Japan & 2 & 121,732 & 1.5 & $1.38(0.17,4.98)$ \\
\hline Australia & 17 & 6,480 & 4.6 & $3.71(2.16,5.93)$ \\
\hline
\end{tabular}

Combined exposure from Europe, North America, Japan and Australia accounts for $86 \%$ of the total cumulative postmarketing exposure and for all cases of melanoma at the data lock point of 10 October 2015.

- Expected cases are based on region-specific incidence rates in the general population (Globocan 2012).

PY, patient years; SIR, standardized incidence ratio; TCZ, tocilizumab.

Conclusions: In clinical trials, no evidence was found to suggest there were more cases of melanoma than expected in patients with RA treated with TCZ compared with the general population. Consistent with this, no evidence was found to suggest that patients with RA treated with TCZ in Europe, North America or Japan had more cases of melanoma than expected compared with the general population in each region. In contrast, the estimated SIR of melanoma in patients with RA treated with TCZ in Australia indicated more than the expected number of cases in the general population. This finding is consistent with reports of elevated risk of melanoma in patients with RA in Australia (compared with the general population), where UV exposure is high and methotrexate is a common first-line therapy. ${ }^{1,2}$

References:

[1] Buchbinder et al. Arthritis Rheum. 2008.

[2] Buchbinder et al. BMC Musculoskelet Disord. 2015.

Acknowledgements: Funded by Roche/Genentech.

Disclosure of Interest: S. Gale Employee of: Genentech, J. Wang Employee of:

Roche, J. Nebesky Employee of: Roche, A. Linke Employee of: Genentech, E. Berber Employee of: Genentech

DOI: 10.1136/annrheumdis-2017-eular.1314

\section{FRI0249 CIRCULATING FOLLICULAR HELPER-LIKE T CELLS IN PATIENTS WITH RHEUMATOID ARTHRITIS TREATED WITH ABATACEPT}

S. Piantoni ${ }^{1}$, M. Scarsi ${ }^{2}$, F. Regola ${ }^{1}$, A. Tincani ${ }^{1}$, P. Airò ${ }^{1} .{ }^{1}$ Rheumatology and Clinical Immunology Unit, Spedali Civili and University of Brescia, Brescia

${ }^{2}$ Internal Medicine Unit, Esine-Vallecamonica Hospital, Esine, Italy

Background: Rheumatoid arthritis (RA) is characterized by synovial inflammation and, in most cases, by autoantibodies, including rheumatoid factor (RF) and anticyclic citrullinated peptide antigen (ACPA), whose presence is associated to a more severe disease. The capability of producing autoantibodies is acquired by $B$ cells with the "help" of specialized T lymphocytes, known as Follicular helper $\mathrm{T}(\mathrm{TFH})$ cells, in the germinal centers (GC) of secondary lymphoid tissues. TFH express the inducible co-stimulator (ICOS), and are characterized by a high expression of CXC-chemokine receptor 5 (CXCR5), which mediate their migration into the GC, where its ligand CXCL13 is expressed. Here, TFH promote the GC development and $\mathrm{B}$ cell maturation. These cells are reported to exist in greater quantities in the peripheral blood (circulating TFH-like cells) of RA patients.

Abatacept $(A B A)$ is a fusion protein, which through its CTLA4 portion can bind to CD80 and CD86 on antigen presenting cells, thereby inhibiting CD28 costimulation. Data from animal models and phenotypic analysis of circulating $T$ cells in RA suggest that ABA may act in the secondary lymphoid organ, and not directly on the synovium $(1,2)$. While experimental models show that ABA can block the generation of TFH (3), little is known on the effect of ABA on circulating TFH-like cells of RA patients (4).

Objectives: To analyze the effect of the blockade of costimulation performed by 